\title{
Monetary incentives to avoid deforestation under the Reducing emissions from deforestation and degradation (REDD)+ climate change mitigation scheme in Tanzania
}

\author{
Meley M. Araya • Ole Hofstad
}

Received: 7 April 2014 / Accepted: 28 August 2014 /Published online: 10 September 2014

(C) The Author(s) 2014. This article is published with open access at Springerlink.com

\begin{abstract}
The paper estimates and compares the level of Reducing Emissions from Deforestation and Degradation (REDD + ) payments required to compensate for the opportunity costs (OCs) of stopping the conversion of montane forest and miombo woodlands into cropland in two agro-ecological zones in Morogoro Region in Tanzania. Data collected from 250 households were used for OC estimation. REDD+ payment was estimated as the net present value (NPV) of agricultural rent and forest rent during land clearing, minus net returns from sustainable wood harvest, divided by the corresponding reduction in carbon stock. The median compensation required to protect the current carbon stock in the two vegetation types ranged from USD $1 \mathrm{tCO}_{2} \mathrm{e}^{-1}$ for the montane forest to USD $39 \mathrm{tCO}_{2} \mathrm{e}^{-1}$ for the degraded miombo woodlands, of which up to $70 \%$ and $16 \%$, respectively, were for compensating OCs from forest rent during land clearing. The figures were significantly higher when the cost of farmers' own labor was not taken into account in NPV calculations. The results also highlighted that incentives in the form of sustainable harvests could offset up to $55 \%$ of the total median OC to protect the montane forest and up to $45 \%$ to protect the miombo woodlands, depending on the wage rates. The findings suggest that given the possible factors that can potentially affect estimates of REDD+ payments, avoiding deforestation of the montane forest would be feasible under the REDD + scheme. However, implementation of the policy in villages around the miombo area would require very high compensation levels.
\end{abstract}

Keywords Agricultural rent - Forest rent - Miombo woodland - Montane forest - Opportunity cost . REDD $+\cdot$ Sustainable harvest

\section{Introduction}

Conversion of forestland to agricultural land has been one of the main proximate causes of tropical deforestation (Barbier and Burgess 1997; Kaimowitz and Angelsen 1998; FAO 2010;

M. M. Araya $(\bowtie) \cdot$ O. Hofstad

Department of Ecology and Natural Resource Management, Norwegian University of Life Sciences (NMBU), P.O. Box 5003, 1432 Ås, Norway

e-mail: meley.araya@nmbu.no 
Kissinger et al. 2012), and subsequent emissions of greenhouse gases and loss of other important ecosystem services (FAO 2010). This activity has been estimated to account for about $80 \%$ of deforestation globally (Kissinger et al. 2012) and up to $12 \%$ of total humaninduced $\mathrm{CO}_{2}$ emissions (van der Werf et al. 2009). Moreover, deforestation due to agricultural expansion is expected to increase in the near future (Kissinger et al. 2012) despite the fact that, for example, tropical forests play an important role in regulating global climate by serving as sinks for carbon, storing about $50 \%$ of the terrestrial organic carbon (FAO 2005). In the global climate change mitigation agenda, this led, in 2008, to the development of the United Nations' policy measure Reducing Emissions from Deforestation and Forest Degradation (REDD), which in 2010 became REDD+ (Reducing Emissions from Deforestation and Degradation, and enhancing forest carbon stocks).

REDD was originally a financial-incentives-based policy measure developed as a means to protect forest carbon stocks from being released into the atmosphere as a result of deforestation and forest degradation (Wertz-Kanounnikoff and Kongphan-apirak 2009; Dudley 2010). REDD+ includes the possibility of offsetting carbon emissions through forest conservation, sustainable management of forests, and enhancement of forest carbon stocks (Bosetti and Rose 2011; Angelsen et al. 2012). Moreover, the policy measure provides a recognized system of payment for ecosystem services related to carbon sequestration and storage, whereby payments are made on the basis of performance (Wunder and Wertz-Kanounnikoff 2009).

REDD+ involves restrictions on local use of forestland and resources. However, about 1.6 billion people depend on tropical forests for their daily needs (World Bank 2004), and about 13 million ha of forest are cleared annually to provide livelihoods, incomes, and employment for millions of people in the tropics (FAO 2010; Kissinger et al. 2012). REDD+ will therefore impose considerable opportunity costs (OCs) on local communities (Wollenberg and SpringateBaginski 2009; Springate-Baginski and Wollenberg 2010). The OCs refer to the net benefits forgone by landowners/users as a result of not deforesting or degrading forests. The idea behind the REDD+ scheme is that such costs should be compensated in order to eliminate or reduce deforestation and forest degradation without affecting the livelihoods of local communities.

Several studies have shown that avoiding deforestation would cost less than USD $5 \mathrm{tCO}_{2}{ }^{-1}$ (Osborne and Kiker 2005; Grieg-Gran et al. 2006; Stern 2007; Bellassen and Gitz 2008; Potvin et al. 2008; Yamamoto and Takeuchi 2012). Even though higher costs have been estimated (e.g., Kindermann et al. 2008; Butler et al. 2009), REDD+ is generally assumed to be a relatively cheap mechanism seen as a cost-effective climate change mitigation mechanism compared to industrial mitigation measures.

Most REDD+ cost estimates are based on payments required to offset OCs as the main cost component. The payments vary considerably among and within regions, depending on a number of ecological and economic factors (Angelsen 2008; Grieg-Gran 2008; Olsen and Bishop 2009). OCs of not converting forests to cropland vary greatly, depending on the types of farming systems and crops. For example, small-scale subsistence farming does not generally generate produce with quantifiable economic value and therefore the estimated OC of stopping such a farming system is usually very low, as shown by several studies (e.g., Bellassen and Gitz 2008; Olsen and Bishop 2009), compared to the cost of paying a landowner/user to not convert forests to large-scale commercial agriculture such as palm oil production (Butler et al. 2009) or soybean cultivation (Kindermann et al. 2008). Most OC calculations overlook the non-monetary benefits derived from agricultural and forestry activity that a landowner/user would forego by not clearing or degrading forests due to the difficulty in calculating them. However, some studies show that incorporating such costs into REDD+ projects increases the level of compensation (Karky and Skutsch 2010), implying that REDD+ compensation schemes may not be as cheap as many estimates suggest. Moreover, compensation values 
estimated for moist tropical forests with carbon densities of greater than $200 \mathrm{tC} \mathrm{ha}^{-1}$ in, for example, Brazil (Olsen and Bishop 2009), Cameroon (Bellassen and Gitz 2008), Guyana (Osborne and Kiker 2005), and Indonesia (Yamamoto and Takeuchi 2012) are very small, below USD $5 \mathrm{tCO}_{2}^{-1}$. However, such estimates cannot be treated as representative of dry tropical forests, such as those Tanzania in which carbon densities are less than $100 \mathrm{tC} \mathrm{ha}^{-1}$ (Munishi et al. 2010). Further, significant variations have been reported in the amount of compensation required to protect relatively intact forests, compared to degraded forests of the same type (Olsen and Bishop 2009). Other factors that affect the compensation estimates include variations in assumptions regarding the cost of labor (mainly family labor), the discount rate, time horizon, the degree of access to forests permitted after the implementation of the policy, and how net costs of conversion are treated (Grieg-Gran 2008; Karky and Skutsch 2010).

The aforementioned issues suggest the need for localized estimates of REDD+ payments and for identifying conditions and factors that will affect the feasibility of the policy measure and thereby inform decisions as to where to establish projects. To address these issues, we therefore conducted a study in Morogoro Region, Tanzania. Two vegetation types representing a humid forest and a dry tropical forest were considered. The main objective of this paper is to estimate and compare monetary incentives required to stop the conversion of montane forest and miombo woodlands into cropland under different cropping systems, and thus evaluate the feasibility of REDD + policy in two agro-ecological zones in Tanzania. In addition, the effects of different assumptions regarding valuing farmers' own labor in crop production as well as possible forest management rules that apply to forest use following the implementation of the scheme on the level of REDD+ payments required are examined to determine their implications for the policy design.

\section{Forest status in Tanzania}

Tanzania possesses about 35 million ha of forests and woodlands, covering $40 \%$ of the country's total land area (FAO 2010). About $90 \%$ of the forested and wooded area is made up of miombo woodlands (Malimbwi et al. 2005). Miombo, a collective name for species of the genera Brachystegia, Julbernardia, and Isoberlinia, is a common vegetation type in large parts of central, south, and eastern Africa (Campbell 1996). Other vegetation types include montane forests, mangrove forests, acacia savannah, and coastal forests (Burgess et al. 2010). About $52 \%$ of the forests and woodlands in the country are within protected areas, and the remaining percentage is on village or general (de facto open access) lands (Zahabu et al. 2007; Mbwambo et al. 2012). Tanzania is one of a number of countries currently experiencing a high rate of deforestation and is planning to implement a REDD+ policy. It has been estimated that the country lost an average of 403,000 ha (about $1.02 \%$ ) of its forests and woodlands per year during the period 1990-2000 (FAO 2010). During the same period, the percentage loss was higher for miombo woodlands (13\%) compared to the Eastern African coastal forest mosaic ( $7 \%$ ), mangrove forest (2\%), and forests of the Eastern Arc Mountains (EAM) (1\%) (Burgess et al. 2010). Between 2000 and 2010, the annual forest loss increased to $1.1 \%$ (FAO 2010). Agricultural expansion has been identified as one of the main drivers of deforestation in Tanzania (Makundi and Okiting'ati 1995; Angelsen et al. 1999; Burgess et al. 2002; Luoga et al. 2005; Kissinger et al. 2012). In addition, particularly the miombo woodlands have been subject to extensive extraction of wood for charcoal making (Monela et al. 1993; Luoga et al. 2005; Nduwamungu et al. 2008). It has been suggested that REDD+ monetary incentives may 
help to reduce the problem of deforestation and degradation in the Tanzania (Zahabu et al. 2007).

\section{Materials and methods}

\subsection{Study sites}

Our socioeconomic survey was conducted in seven villages within Morogoro Region: Kunke, Maseyu, Mlimbilo, Ng'ungulu, Nyandira, Tchenzema, and Vinile (Fig. 1). The first three aforementioned villages are located at an average altitude of $400 \mathrm{~m}$ a.s.l., hereafter referred to as the lowland zone. The remaining four villages are located between 1,000 m a.s.l. and $2,668 \mathrm{~m}$ a.s.1., hereafter referred to as the highland zone. The two agro-ecological zones comprise two distinct vegetation types: miombo woodlands in the lowland zone and montane forest in the highland zone.

Kunke and Mlimbilo are located in Mtibwa Ward, $120 \mathrm{~km}$ north of Morogoro town. The villages cover an area of about 24,000 and 13,600 ha and have about 3,500 and 2,000 inhabitants, respectively. The climate of the area is sub-humid tropical, with a mean annual rainfall in the range of $800-1,200 \mathrm{~mm}$. There are two rainy seasons, the short rains from October to December and the long rains from March to June. Mean annual temperature varies between $28^{\circ} \mathrm{C}$ and $31^{\circ} \mathrm{C}$. The area includes settlements, a sugar factory, croplands, sugarcane (Saccharum officinarum L.) and teak (Tectona grandis L. leaf) plantations, grazing land, open scattered miombo woodlands, and part of a protected miombo woodland known as the WamiMbiki wild animals management area (WMA). The inhabitants depend mainly on agriculture for their livelihoods. They practice small-scale and medium-scale farming and cultivate crops for subsistence [maize (Zea mays L.)] and for marketing [rice (Oryza glaberrima S.), sesame (Sesamum indicum L.), and sugarcane]. WMA is a community-based conservation area that was established in 1999. The area is located in two regions, Morogoro Region and Tanga Region. It covers a core area of about $3,000 \mathrm{~km}^{2}$ and a buffer area of about $1,200 \mathrm{~km}^{2}$ (Madulu 2005). The WMA is surrounded by 24 villages including Kunke and Mlimbilo, and houses about 65,000 people in total; it covers $65 \%$ of Kunke and $47 \%$ of Mlimbilo. The woodlands inside the WMA have suffered from extensive tree cutting for charcoal production, and agricultural expansion and encroachment.

Maseyu is located in Gwata Ward, about $50 \mathrm{~km}$ northeast of Morogoro town and $150 \mathrm{~km}$ west of Dar es Salaam (Fig. 1). The climatic conditions and rainfall pattern in Gwata Ward are similar to those in Mtibwa Ward. The village of Maseyu covers approximately 36,000 ha and has about 2,000 inhabitants. It comprises settlements, croplands, open miombo woodlands, village reserves, part of Kitulangalo Forest Reserve (KFR), and a part of the WMA. About $80 \%$ of the households depend on crop production (Nduwamungu et al. 2008). The local farming system is characterized by small-scale rain-fed crop cultivation for both subsistence consumption [maize, millet (Eleusine coracana L.), and sorghum (Sorghum bicolor L.)] and for marketing (sesame). The inhabitants are highly dependent on forest resources in protected and unprotected woodlands, both for their own consumption (firewood, fruit and vegetables, and wood for poles) and for commercial purposes (charcoal). The KFR spans two villages: Gwata and Maseyu. The reserve covers an area of about 435 ha in Gwata and 1,705 ha in Maseyu. The vegetation type is generally characterized as open, dry miombo that is dominated by the tree species Julbernadia globiflora, Brachystegia boehmii, and Pterocarpus rotundifolius (Luoga et al. 2000). The part of the forest reserve located in Maseyu is managed jointly by the central government and the village, while the part in Gwata is managed by the 

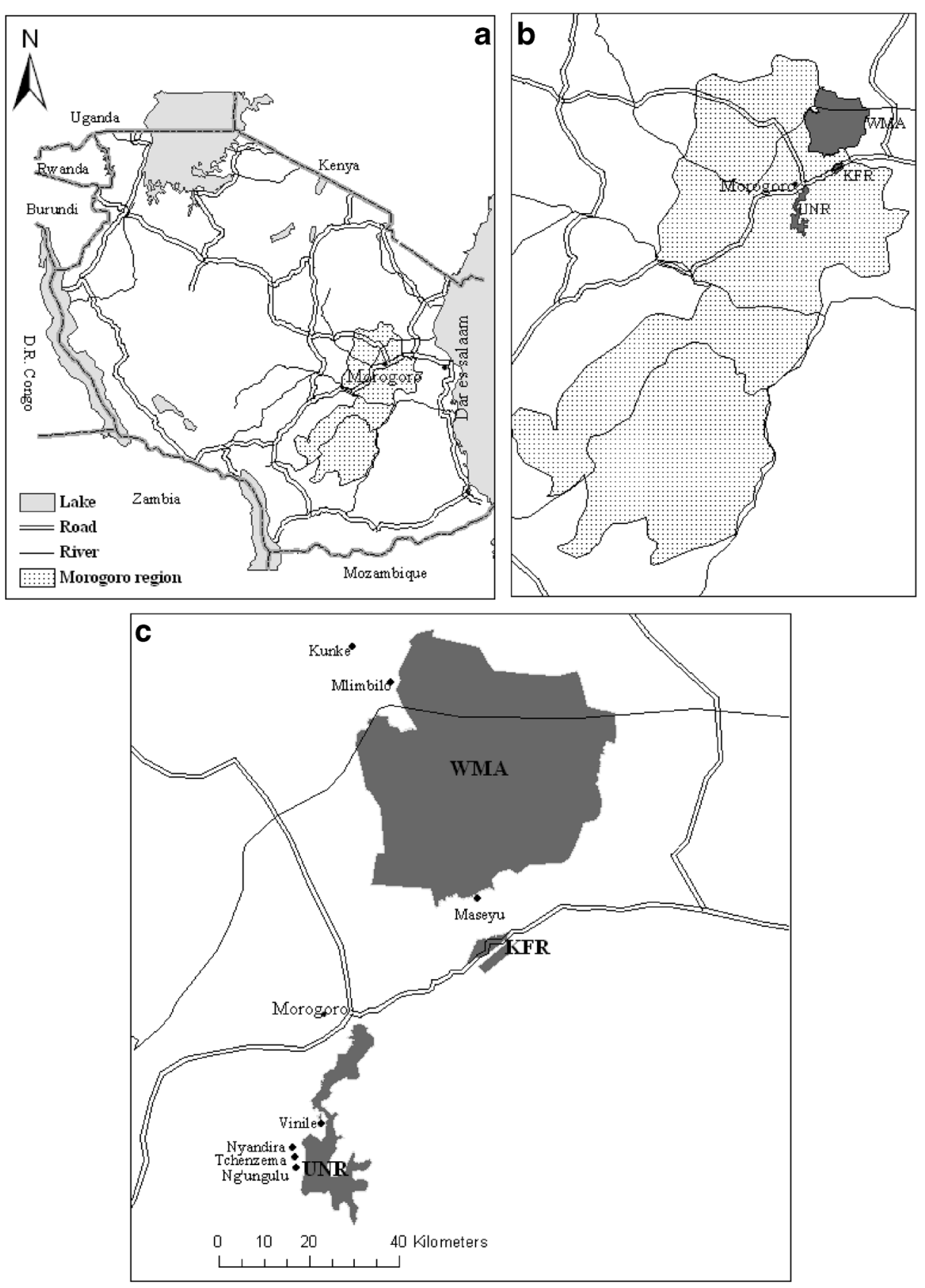

Fig. 1 Tanzania (a), the location of Morogoro region (b), and the study villages and protected forests within the region $(\mathbf{c})$

central government through Sokoine University of Agriculture in Morogoro town. The KFR was established in 1985 (Luoga et al. 2002). However, the current management systems have been practiced since 1995 in Gwata and since 2000 in Maseyu. The reserve is formally 
protected, but in practice, tree cutting is common practice and there have been some cases of conversion into agricultural land. An estimated $1.2 \mathrm{~m}^{3} \mathrm{ha}^{-1}$ of wood is illegally harvested from the reserve annually (Luoga et al. 2002). Moreover, in the period 1975-2000, closed woodland in the reserve and the surrounding area declined by $45 \%$, while open woodland in the surrounding area increased by $42 \%$ (Nduwamungu et al. 2008).

Ng'ungulu, Nyandira, Tchenzema, and Vinile are located in Mgeta Division, about $200 \mathrm{~km}$ west of Dar es Salaam (Fig. 1). Mgeta Division covers an area of $1,800 \mathrm{~km}^{2}$ and includes four wards and 28 villages with a total population of about 46,000 . The climate in the area is tropical, with an average annual rainfall in the range of 1,000-2,000 $\mathrm{mm}$. The rainy season lasts from November to May. The mean annual temperature varies from $15{ }^{\circ} \mathrm{C}$ to $21{ }^{\circ} \mathrm{C}$ (Kapilima 1994). The surrounding farmlands extend up to the border of Uluguru Nature Reserve (UNR), at about 2,000 m a.s.l., but rarely extend into the reserve (Frontier-Tanzania 2005). The inhabitants in areas to the UNR practice intensive small-scale farming of both subsistence crops [maize and pulses such as beans (Phaseolus vulgaris L.), chickpeas (Cicer arietinum L.), and peas (Pisum sativum L.)] and cash crops [vegetables such as cabbage (Brassica oleracea L.), potato (Solanum tuberosum L.), and tomato (Solanum lycopersicum L.)], and rely mainly on family members for labor. The UNR is part of the EAM, a chain of mountains stretching from the Taita Hills in southern Kenya through eastern Tanzania to the Udzungwa Mountains of south-central Tanzania. The nature reserve covers an area of approximately $24 \mathrm{~km}^{2}$ and is surrounded by 57 densely populated villages (FBD 2009). It consists of sub-montane forests (below 1,500 m a.s.1.), montane forests (1,600-2,400 m a.s.l), and upper montane forests (above 2,400 $\mathrm{m}$ a.s.1), and receives the highest rainfall (up to 4,000 mm year ${ }^{-1}$ ) in Tanzania (Lovett and Pócs 1993). Rivers originating in the reserve are the main supply of water to the local communities, as well as to Morogoro town and Dar es Salaam (Lundgren 1978). The UNR is one of the world's biodiversity hotspots (Poynton et al. 2007). It also plays an important role as a carbon reservoir, currently storing about 10.3 million tons of carbon (FBD 2010). The reserve, which is managed by the central government, has been protected since the 1910s; in 1950, it was gazetted, and since then the cutting of trees has been officially prohibited. However, illegal harvesting of wood from the UNR has continued. Moreover, between 1955 and 2000, $25 \%$ of the forest was lost, mainly due to agricultural expansion (Burgess et al. 2002). To mitigate the impact, the government allowed households in the surrounding villages to collect firewood, fruits, herbs, and other non-wood forest products for their own consumption, two times per week (FBD 2009). Uluguru Nature Reserve comprises four separate forest reserves, Uluguru North FR, Uluguru South FR, Bunduki FR, and Bunduki Gap FR. Our study was conducted in Mgeta Division, which covers the southwestern side of the Uluguru Mountains, within Uluguru South FR.

\subsection{Data}

The data were collected over the course of 5 months, between September 2011 and January 2012, from communities located in the seven study villages. A total of 112 households were randomly selected from the four villages in Mgeta Division (Ng'ungulu, Nyandira, Tchenzema, and Vinile), 65 from the two villages in Mtibwa Ward (Kunke and Mlimbilo), and 54 from the village of Maseyu in Gwata Ward. Basic demographic information, as well as information relating to costs and revenues associated with crop production and forestry, local prices of all inputs and outputs, as well as labor costs, was obtained using structured questionnaires. Further information was collected through focus group discussions to triangulate and verify the information obtained from households as well as to obtain qualitative information. In addition, we visited local market places to gather information on prices of 
inputs and outputs. Moreover, secondary sources were used to obtain data on the carbon storage potential of different types of vegetation and land uses.

\subsubsection{Estimating REDD+ payments to offset OCs}

The $\mathrm{OC}$ of forest protection can be defined as the forgone net benefits from the best alternative land uses (Bond et al. 2009; Olsen and Bishop 2009; Angelsen et al. 2012) and are payments required to compensate forest owners or users for their forgone benefits (Angelsen 2008). REDD+ payments to offset OCs can be estimated as the net present value (NPV) of the next best use of forestland divided by the associated reduction in carbon stock (Wertz-Kanounnikoff 2008). OC estimates will depend on the rules that apply to forest use after the REDD+ contract has been signed. For simplicity, we assumed that deforestation should stop immediately, while wood harvesting could continue in a sustainable way. Here we defined sustainable harvest as the mean annual increment (MAI) of the forest or woodland under consideration. We therefore estimated the REDD+ payments to offset the OCs of stopping conversion of the two vegetation types considered in our study as the NPV of agricultural rent and forest rent during land clearing, minus the net returns from sustainable wood harvest, divided by the corresponding possible reduction in carbon stock.

\subsubsection{Estimating agricultural rent}

Data on crop production were collected from 606 sample plots. The size of the sample plots ranged from 0.1 to 2.0 ha in Mgeta Division, 0.4 to 5.0 ha in Mtibwa Ward, and 0.4 to 6.0 ha in Gwata Ward. The percentage share of each crop type cultivated in each village is presented in Table 1 . We estimated the financial returns from the major crops grown at each village. The costs of crop production included the cost of land clearing, seeds, fertilizers, pesticides and fungicides, labor required for different activities, and transportation to the local market, and we obtained from local markets the prices of each input and each type of crop produce. The median yield and average price of the major crops cultivated in each village are summarized in Tables 2 and 3, respectively. Due to the difficulty of valuing a farmer's own labor (Fisher et al. 2005; Le 2009), we applied and compared three different wage rates: (1) the reported wage rate in the study villages (hereafter referred to as the "village wage rate"), (2) the minimum wage rate for agricultural labor in Tanzania ("minimum wage rate"), and (3) a wage rate equal to zero ("zero wage rate") which assumed an opportunity cost of labor as zero. The net benefit (NB) of each crop type was calculated

Table 1 Percentage share of crops cultivated in each study village

\begin{tabular}{|c|c|c|c|c|c|c|c|c|c|c|}
\hline \multirow[t]{2}{*}{ Village } & \multicolumn{10}{|c|}{ Crop type (\% share) } \\
\hline & Maize & Sugarcane & Rice & $\begin{array}{l}\text { Maize } \\
\text { and } \\
\text { sesame }\end{array}$ & $\begin{array}{l}\text { Maize } \\
\text { and } \\
\text { millet }\end{array}$ & $\begin{array}{l}\text { Millet } \\
\text { and } \\
\text { sesame }\end{array}$ & Vegetables & Pulses & $\begin{array}{l}\text { Maize } \\
\text { and } \\
\text { pulses }\end{array}$ & $\begin{array}{l}\text { Maize and } \\
\text { vegetables }\end{array}$ \\
\hline Kunke & 50 & 13 & 16 & 21 & & & & & & \\
\hline Maseyu & 49 & & & 18 & 18 & 15 & & & & \\
\hline Mlimbilo & 76 & 6 & 14 & 4 & & & & & & \\
\hline Ng’ungulu & 19 & & & & & & 1.5 & 4 & 74 & 1.5 \\
\hline Nyandira & 8.5 & & & & & & 13 & 6 & 50 & 22.5 \\
\hline Tchenzema & 11 & & & & & & 4 & 10 & 47 & 28 \\
\hline Vinile & 13 & & & & & & & & 74 & 13 \\
\hline
\end{tabular}


Table 2 Median harvest (ton $\mathrm{ha}^{-1}$ ) of the major crops cultivated in each study village

\begin{tabular}{|c|c|c|c|c|c|c|c|}
\hline \multirow[t]{2}{*}{ Crop type } & \multicolumn{7}{|l|}{ Village } \\
\hline & Kunke & Maseyu & Mlimbilo & Ng'ungulu & Nyandira & Tchenzema & Vinile \\
\hline Maize & 1.24 & 0.62 & 0.99 & 0.49 & 1.78 & 0.67 & 0.20 \\
\hline Sugarcane & 19.77 & & 49.00 & & & & \\
\hline Sesame & 0.50 & 0.30 & 0.86 & & & & \\
\hline Rice & 0.88 & & 0.53 & & & & \\
\hline Vegetables & & & & 0.49 & 1.73 & 3.08 & \\
\hline Pulses & & & & 0.49 & 0.37 & 0.30 & 0.43 \\
\hline
\end{tabular}

as the difference between the total value of the crop harvest and the value of all production factors except land. Assuming that present agricultural practices are sustainable and that the relative prices of products and factors are constant, the NPV of land can be calculated as annual NBs divided by a constant discount rate. However, the assumption that the current yield estimates can reflect past and future yield values might lead to underestimates or overestimates of past and future estimates, respectively, as the croplands considered in our study were not representative of recently deforested lands. Further, the choice of the appropriate discount rate is far from an obvious and straightforward decision (Howarth and Norgaard. 1992). We chose a nominal discount rate based on the rate of lending by the Bank of Tanzania as of January 2011 (12\%) (BOT 2011). The real interest rate (r) was estimated by adjusting the nominal discount rate for inflation using the Fisher equation

$$
r=\frac{1+i}{1+\pi}-1
$$

Where $i$ is the nominal interest rate and $\pi$ is the inflation rate. The inflation rate of all items for the period January 2010 to January 2011 was $6.4 \%$ (BOT 2011). Accordingly, we used a discount rate of $5.3 \%$. The median agricultural NPV per hectare in each village was obtained using the formula

$$
\mathrm{NPV}=\mathrm{FR}+\alpha_{\mathrm{i}}\left(\mathrm{NB}_{\mathrm{i}} / r\right)+\ldots \alpha_{\mathrm{n}}(\mathrm{NBn} / r)
$$

\begin{tabular}{|c|c|c|c|c|c|c|}
\hline \multirow[t]{2}{*}{ Village } & \multicolumn{6}{|c|}{ Price (USD kg ${ }^{-1}$ ) } \\
\hline & Maize & Sugarcane & Sesame & Rice & Vegetables & Pulses \\
\hline Kunke & 0.22 & 0.17 & 0.82 & 0.91 & & \\
\hline Maseyu & 0.25 & & 0.64 & & & \\
\hline Mlimbilo & 0.22 & 0.02 & 0.48 & 0.93 & & \\
\hline Ng'ungulu & 0.34 & & & & 0.29 & 0.27 \\
\hline Nyandira & 0.26 & & & & 0.16 & 0.47 \\
\hline Tchenzema & 0.29 & & & & 0.14 & 0.39 \\
\hline Vinile & 0.27 & & & & & 0.38 \\
\hline
\end{tabular}

Table 3 Average price (USD kg${ }^{-1}$ ) of the major crops cultivated in each study village 
Table 4 Economic parameters used to estimate rents to firewood, poles, timber, and tool handles

\begin{tabular}{lcllc}
\hline Product type & Quantity per hectare & Unit & Labor cost per unit (USD) & Price per unit (USD) \\
\hline Firewood & 0.90 & Ton & 0 & 106.00 \\
Poles & 170 & Each & 1.62 & 12.72 \\
Timber & 15.32 & $\mathrm{~m}^{3}$ & 39.60 & 56.71 \\
Tool handles & 513 & Each & 0.32 & 0.64 \\
\hline
\end{tabular}

where FR is the net revenue obtained per hectare from forest clearing, $\mathrm{NB}_{i}$ represents the median NBs per hectare from the $i$ th most cultivated crop in each village, $\alpha \in[0,1]$ is the ratio of cultivation of $i$ th crop per hectare, and $r$ is the real discount rate.

\subsubsection{Estimating forest rent}

Montane forest The montane forests are extensively used for harvesting wood for tool handles, poles, and timber. The tree species used for these products were identified and their net profits were estimated. Timber-producing species account for approximately $25 \%$ of the total average standing volume $\left(319 \mathrm{~m}^{3} \mathrm{ha}^{-1}\right)$. Tree species important for making poles and tool handles accounted for respectively $11 \%$ and $16 \%$ of the total average tree density ( 539 stems ha $^{-1}$ ). Timber volume was estimated using $63 \%$ log recovery and $30 \%$ timber recovery (Muthike et al. 2013). In contrast to the production of agricultural produce in the studied villages, the production of logs and timber requires labor that is more skilled. Hence, it is assumed that labor is hired for these activities. Wood extracted for making the different products is considered to be a free good and thus is available free of cost to the producer.

The collection of firewood from the reserve is assumed to be less or equal to the MAI of the forest, and therefore sustainable harvesting means only the collection of firewood. A household collects two head loads of firewood per week, and an average weight of a head load is about $13 \mathrm{~kg}$ (Mitinje et al. 2007). About 16,000 households depend on the nature reserve for firewood. The total biomass of firewood collected per hectare was therefore estimated as the number of households multiplied by the average annual consumption of a household divided by the total area of the forestland. The NPV was then calculated by dividing the value by the real interest rate, which was $5.3 \%$. The economic parameters that we used to estimate rents to firewood, poles, timber, and tool handles are presented in Table 4.

Miombo woodlands Most of the information on the miombo woodlands was derived from the data we collected from the village of Maseyu (Gwata Ward), and we assumed that the collected data were also representative of similar miombo woodlands in Mtibwa Ward. The average standing volume on public land (degraded miombo) is $14 \mathrm{~m}^{3} \mathrm{ha}^{-1}$ (Zahabu 2008). We estimated that the average standing volume in the forest reserve (dense miombo) in 2011 was $65 \mathrm{~m}^{3} \mathrm{ha}^{-1}$, on the basis of inventory data that was collected in the same year. The MAI of the woodlands around the study villages is estimated to be $2.9 \mathrm{Mg} \mathrm{ha}^{-1}$ for regrowth miombo and $3.7 \mathrm{Mg} \mathrm{ha}^{-1}$ for old-growth miombo (Ek 1994), equivalent to a volume of $3.41 \mathrm{~m}^{3} \mathrm{ha}^{-1}$ and $4.35 \mathrm{~m}^{3} \mathrm{ha}^{-1}$, respectively, using a 0.85 conversion factor from biomass (ton) to volume $\left(\mathrm{m}^{3}\right)$ (Malimbiwi et al. 1994). Tree species used for charcoal making represent $40 \%$ of the standing volume. One cubic meter of wood yields $4.3 \mathrm{bags}$ of charcoal (56 kg/bag), and the labor required to produce one bag of charcoal is 2.3 person-days (Hofstad 1997; Luoga et al. 2002). The cost of physical inputs, such as axes, machetes, and rope, is approximately USD 6.4. Such inputs are assumed to last for 5 years. We found that the average price of one 
bag of charcoal ranged from USD 5 at the kiln site to USD 6.3 at the road side. The same assumption as for the agricultural rent was made for estimating cost of labor required for different activities such as felling and cross-cutting of trees, log piling, stacking, and loading and unloading charcoal kilns. The same assumption as for the montane forest products was made about value of wood extracted for charcoal production.

\subsubsection{Estimating carbon stocks in forests, woodlands, and agricultural lands}

Data on carbon stocks in different pools of the two studied forest types (miombo and montane forest) and surrounding agricultural lands were obtained from various published sources (Table 5). Averages were taken when more than one estimate per vegetation type was available. A rough estimation of biomass was also made in the WMB area and the surrounding open woodland for comparison with the biomass data obtained from other miombo woodlands. Ten plots were sampled using an inventory design proposed by the National Forestry Resources Monitoring and Inventory of Tanzania and similar biomass densities were found in WMB as reported for miombo (Luoga et al. 2002). The below-ground biomass of miombo woodlands was estimated as $20 \%$ of the above-ground biomass. The soil carbon of croplands in original miombo woodlands was estimated at $60 \%$ of soil carbon in miombo woodlands (Walker and Desanker 2004). The carbon estimate was multiplied by the conversion factor of 3.67 to obtain tons of carbon dioxide equivalents $\left(\mathrm{tCO}_{2}\right)$. The net carbon or equivalent carbon dioxide that will be protected under the REDD+ scheme was estimated as the mean of the total carbon storage of each vegetation type minus the mean of the total carbon storage under the corresponding alternative land use (i.e., agriculture).

\subsubsection{Data analysis}

Of the 606 sample plots, 593 were used for analysis after the data were cleaned. The remaining plots were omitted from the analysis due to incomplete information (e.g., because crops had not been harvested). To avoid the problem of non-normality caused by the fact that profitability

Table 5 Distribution of carbon stock $\left(\mathrm{Mg} \mathrm{ha}^{-1}\right)$ by carbon pool in different land-use categories in the lowland and highland agro-ecological zones in Tanzania

\begin{tabular}{|c|c|c|c|c|c|c|c|c|}
\hline $\begin{array}{l}\text { Agro- } \\
\text { ecological } \\
\text { zone }\end{array}$ & Land-use type & $\begin{array}{l}\text { Above- } \\
\text { ground } \\
\text { biomass }\end{array}$ & $\begin{array}{l}\text { Dead } \\
\text { wood }\end{array}$ & Litter & $\begin{array}{l}\text { Below- } \\
\text { ground } \\
\text { biomass }\end{array}$ & Soil & Total & Source $^{a}$ \\
\hline \multirow[t]{3}{*}{ Highland } & $\begin{array}{l}\text { Afro-montane } \\
\text { forest (a) }\end{array}$ & 222.0 & 11.0 & 13.0 & 54.0 & 295.0 & 595.0 & (2), (7) \\
\hline & Crop land (b) & 3.3 & 0.1 & 0.3 & 0.9 & 123.0 & 127.6 & (7) \\
\hline & Net loss (a-b) & & & & & & 467.4 & \\
\hline \multirow[t]{5}{*}{ Lowland } & $\begin{array}{l}\text { Dense miombo } \\
\text { woodland (a) }\end{array}$ & 20.0 & - & - & 4.0 & 78.5 & 102.5 & $\begin{array}{c}(1),(3),(4), \\
(5),(6)\end{array}$ \\
\hline & $\begin{array}{l}\text { Degraded miombo } \\
\text { woodland (b) }\end{array}$ & 3.5 & & & 0.7 & 78.5 & 82.7 & $(4),(8)$ \\
\hline & Cropland (c) & 0.6 & & & & 47.1 & 47.7 & (6) \\
\hline & Net loss $(\mathrm{a}-\mathrm{c})$ & & & & & & 54.8 & \\
\hline & Net loss $(b-c)$ & & & & & & 35.0 & \\
\hline
\end{tabular}

a Sources: (1) Chamshama et al. 2004; (2) Munishi and Shear 2004; (3) Munishi et al. 2010; (4) Ryan et al. 2011; (5) Shirima et al. 2011; (6) Walker and Desanker 2004; (7) Willcock et al. 2012; (8) Zahabu 2008 
on many plots was low while profitability on a few plots was very high, a Kruskal-Wallis test was used to detect statistically significant differences in the median NPVs of crop production as well as the median compensation estimates between the two agro-ecological zones and among the study villages within the zones. Non-parametric multiple pair-wise comparisons between different parameters were made using Tukey's test and $t$ tests, with a significance level of $\alpha=0.05$. The statistical software $\mathrm{R}$ version 3.0.1 (R Core Team 2013) was used for analysis and SigmaPlot version 11 (Systat Software Inc. 2008) was used for plotting.

\subsubsection{Sensitivity analysis and elasticity estimation}

The analysis in the base case scenario assumed a constant value for each parameter (crop yield, carbon density, prices of the different crop types, and discount rates). However, these variables may have changed over time, thus affecting the results of the analysis. Therefore, to assess the sensitivity of the base case results to changes in the most important parameters, a sensitivity analysis was conducted by making changes in key variables. Changes in discount rate and carbon stock value were considered in the analysis. Based on an assumption that the current discount rate $(5.3 \%)$ was quite low, we examined the effect of increasing the discount rate to $10 \%$. For the carbon stock, reductions and increases of up to $50 \%$ were assumed. Changes in carbon stocks can be caused by fire, uncertainties in carbon stock estimates (Pelletier et al. 2012), or enhanced growth due to different forest management interventions. Moreover, we obtained the elasticity of results to changes in crop yield from an estimated production function.

\section{Results}

\subsection{Agricultural rent}

Figure 2 shows the interquartile range (IQR) of the NPV estimates of each crop type across each study village and each agro-ecological zone. The median NPV estimates varied greatly across crop types, regardless of the wage rates applied. Maize cultivated with vegetables yielded a significantly higher $(p<0.001)$ median NPV in the highland villages, while sugarcane and rice yielded a significantly higher $(p<0.001)$ median NPV in the lowland villages. Depending on the wage rates used, the median NPV estimates also showed variation between the two agro-ecological zones; when the positive wage rates were considered, the median NPV of all the major crops was significantly higher in the lowland zone compared to in the highland zone. However, when the zero wage rate was considered, the median NPV tended to be higher in the highland zone, albeit not significantly (Fig. 3). Similarly, a significant variation in median NPV values between the study villages in the highland zone was observed when only one of the positive wage rates was used (Table 6). However, in the lowland zone, the median NPV between the villages showed significant variation regardless of the wage rates applied (Table 6). The results of the non-parametric multiple comparisons also confirmed variations in the median NPV between villages within the same agro-ecological zone. In the highland zone, when either of the positive wage rates was used, the median NPV estimate for Nyandira was significantly higher compared to the other three villages. However, differences in the median NPV value between the three villages, Ng'ungulu, Tchenzema, and Vinile, were insignificant. When the zero wage rate was considered, the median NPV estimate did not show significant differences among the villages. In the lowland zone, regardless of wage rate used, the median NPV estimate was significantly higher for Kunke compared to for Maseyu and Mlimbilo. 

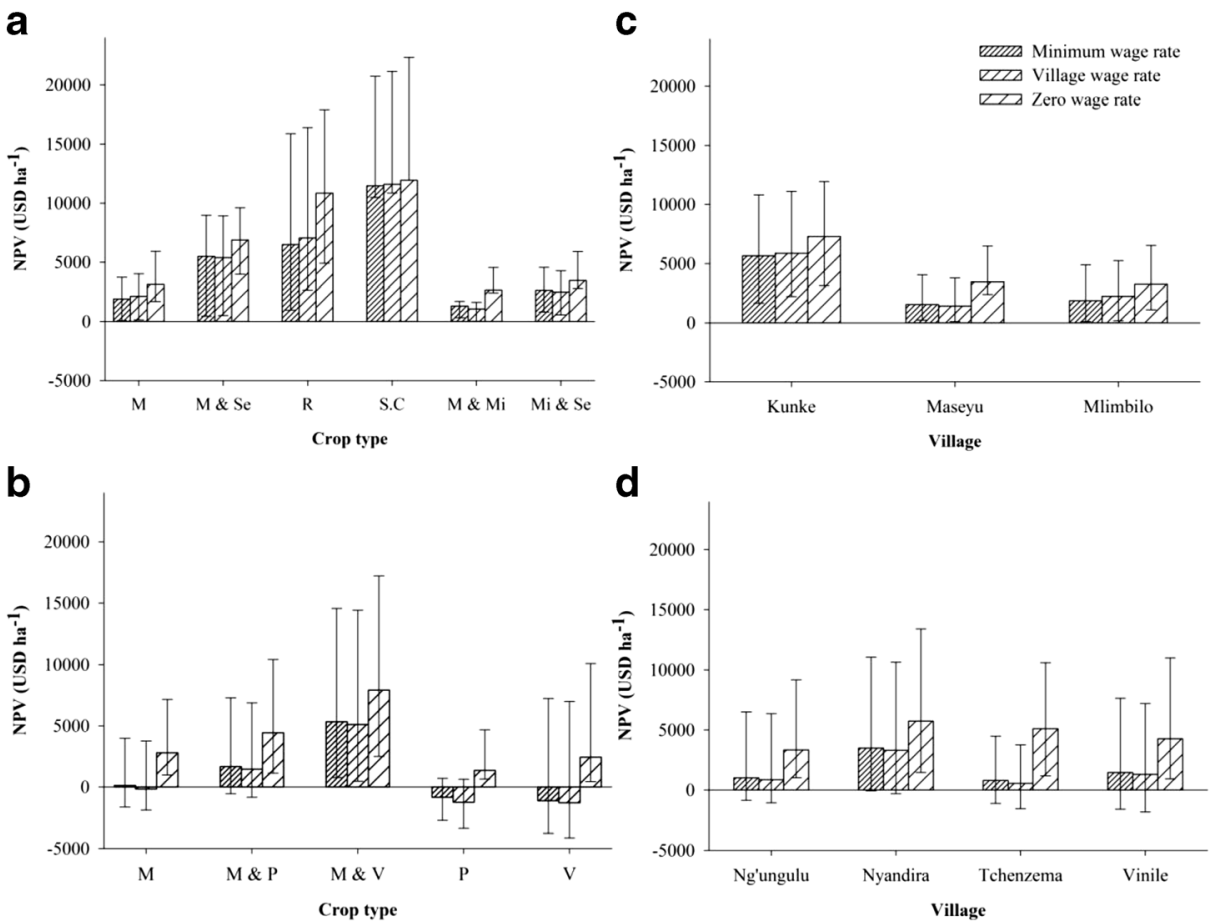

Fig. 2 The median NPV (USD ha ${ }^{-1}$ ) of crop production by crop type (a, b), village (c, d) from the lowland zone $(\mathbf{a}, \mathbf{c})$, and the highland zone (b, d); the lower and upper error bars represent the first and third quartiles, respectively. $M$ maize, $M i$ millet, $P$ pulses, $R$ rice, $S$. $C$ sugarcane, $S e$ sesame, $V$ vegetables

However, the variation in the median NPV estimate for Maseyu and Mlimbilo was not significant. The difference in the NPV values (USD ha ${ }^{-1}$ ) for the same crop types was also very high, with the IQR ranging between 884 for maize cultivated with millet and 14,380 for rice in the lowland zone, and between 3,207 and 13,324, respectively, for pulses and maize cultivated with vegetables in the highland zone. When the zero wage rate was considered, the IQR values showed a slight increase.

The different wage rates resulted in significantly different median NPV estimates for the major crops in all villages, except for Kunke (Table 7). Further, non-parametric multiple comparisons showed that the median NPV values estimated using a zero wage rate were significantly higher compared to estimates using both minimum and village wage rates. However, the minimum and village wage rates yielded similar median NPV estimates in both agro-ecological zones.

\subsection{Forest rent}

In the montane forest, the net returns per hectare from the different forest products during forest clearing was estimated to be USD 1,887 from poles, USD 262 from timber, and USD 160 from tool handles. The NPV of firewood collection was estimated as USD 1,797 ha ${ }^{-1}$. The returns from the sustainable harvest were significantly higher compared to the returns from the other forest products during forest conversion. Table 8 lists the net returns from charcoal burning both during clearing and from annual sustainable harvest in the miombo woodlands. 


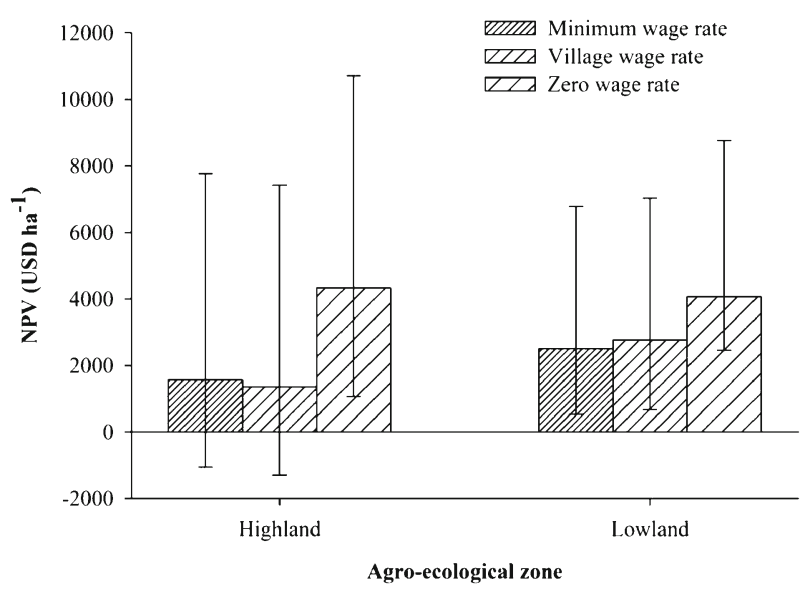

Fig. 3 The median NPV (USD ha ${ }^{-1}$ ) of crop production in the highland and lowland zones; the lower and upper error bars represent first and third quartiles, respectively

The results shows that regardless of the wage rates used, NPV estimates of annual sustainable charcoal production for both the forest reserve and the public land resulted in a relatively higher value compared to the return from charcoal production during conversion. With regard to the wage rates, as in the case of crop production, the NPV values estimated by using the zero wage rate were found to be significantly higher than those estimated using the two other wage rates.

\subsection{The OCs of stopping conversion of forestland to cropland}

The net median income (USD ha ${ }^{-1}$ ) that would be lost from not converting forestland into cropland was in the range of USD 1,289-6,277, depending on the wage rates considered (Table 9). With regard to village wage rate, both the lowest estimates (USD 2,289) and the highest (USD 5,006) estimates were observed in the lowland zone. However, when zero wage rate was used, the lowest estimate (USD 2,719) was observed in the lowland while the highest (USD 6,277) was in the highland (Table 9). The return from forest products during land clearing accounted for up to $16 \%$ of the total median OC in the lowland zone and $70 \%$ in the highland zone, depending on the wage rates considered and the biomass density of the miombo woodlands. When the village wage rate was used, the OCs from forest rent during forest conversion represented $64 \%$ in the highland zone and $10 \%$ in the lowland zone. The results also indicated that incentives from sustainable annual wood harvest could offset up to $45 \%$ of the total median OCs of protecting the miombo woodlands in forest reserves and up to

Table 6 Variations in the median NPV of crop production between the study villages within the two agroecological zones

\begin{tabular}{|c|c|c|c|c|c|c|}
\hline \multirow[t]{2}{*}{ Agro-ecological zone } & \multicolumn{2}{|l|}{ Minimum wage rate } & \multicolumn{2}{|l|}{ Village wage rate } & \multicolumn{2}{|l|}{ Zero wage rate } \\
\hline & Kruskal-Wallis $\chi^{2}$ & $p$ value & Kruskal-Wallis $\chi^{2}$ & $p$ value & Kruskal-Wallis $\chi^{2}$ & $p$ value \\
\hline Lowland & 15.17 & $<0.001$ & 21.24 & $<0.001$ & 16.44 & $<0.001$ \\
\hline Highland & 9.45 & 0.02 & 10.66 & 0.01 & 4.58 & 0.2 \\
\hline
\end{tabular}


Table 7 Variations in the median NPV of crop production estimated using the different wage rates in each study village

\begin{tabular}{llrr}
\hline Agro-ecological zone & Village & Kruskal-Wallis $\chi^{2}$ & $p$ value \\
\hline Lowland & Kunke & 4.22 & 0.12 \\
& Maseyu & 18.18 & $<0.001$ \\
& Mlimbilo & 5.73 & 0.049 \\
Highland & Ng'ungulu & 24.95 & $<0.001$ \\
& Nyandira & 8.29 & 0.015 \\
& Tchenzema & 20.86 & $<0.001$ \\
& Vinile & 20.74 & $<0.001$ \\
\hline
\end{tabular}

$40 \%$ for the miombo woodlands on public land, depending on the wage rates used. Similarly, the sustainable collection of firewood in the highland could offset about $55 \%$ of the estimated total median $\mathrm{OC}$ with regard to the positive opportunity cost of labor.

\subsection{REDD+ payments to offset OCs}

The level of compensation required to reduce emissions of $\mathrm{CO}_{2}$ by stopping the conversion of forestland to cropland differed significantly $(p<0.001)$ in the two agro-ecological zones, and hence also for the different vegetation types, regardless of the wage rates used (Fig. 4); it was significantly higher in the study villages in the lowland zone. With regard to the village wage rate, the median compensation required to protect the current carbon stocks in the different vegetation types varied from USD $1 \mathrm{tCO}_{2}^{-1}$ for the montane forest to USD $39 \mathrm{tCO}_{2}^{-1}$ for the miombo on public land (Table 9). The zero OC of labor increased the median compensation value to USD $3 \mathrm{tCO}_{2}^{-1}$ in the highland zone and to USD 43 in the lowland (Table 9). Regardless of the wage rate used, the median compensation estimates were also found to vary between villages within the same agro-ecological zones. When the village wage rate was considered, the median compensation ranged from USD $1 \mathrm{tCO}_{2}^{-1}$ for Ng'ungulu, Tchenzema, and Vinile to USD $3 \mathrm{tCO}_{2}{ }^{-1}$ for Nyandira in the highland zone, and from USD $7 \mathrm{tCO}_{2}{ }^{-1}$ for Maseyu to USD $39 \mathrm{tCO}_{2}{ }^{-1}$ for Kunke in the lowland zone for the miombo woodlands on public land (Table 9). With regard to the zero wage rate, compensation estimates increased significantly, except for Kunke. With regard to the zero wage rate, when the compensation levels were calculated for each major crop separately, the variation in median compensation was high, ranging from USD $1 \mathrm{tCO}_{2}^{-1}$ for crops cultivated in the highland zone to USD $81 \mathrm{tCO}_{2}^{-1}$ for crops cultivated on formerly degraded miombo woodland in the lowland zone (Fig. 4). The OCs of avoiding cultivation of the most profitable crops after deforesting the

Table 8 NPV of charcoal production during forest conversion and through annual sustainable harvest

\begin{tabular}{lllrl}
\hline \multirow{2}{*}{ Legal status } & Activity & \multicolumn{2}{l}{ NPV (USD ha $\left.{ }^{-1}\right)$} & \\
\cline { 3 - 4 } & & Minimum wage rate & Village wage rate & Zero wage rate \\
\hline \multirow{2}{*}{ Public woodland } & Clearing & 52 & 82 & 161 \\
& Annual sustainable harvest & 554 & 856 & 1,644 \\
Forest reserve & Clearing & 262 & 400 & 763 \\
& Annual sustainable harvest & 715 & 1,100 & 2,106 \\
\hline
\end{tabular}


Table 9 Opportunity costs of stopping conversion of forestland into cropland and the required REDD+ payments to offset those costs

\begin{tabular}{|c|c|c|c|c|c|c|c|}
\hline \multirow{2}{*}{$\begin{array}{l}\text { Vegetation } \\
\text { type }\end{array}$} & \multirow[t]{2}{*}{ Village } & \multicolumn{3}{|c|}{ NPV (OC) $\left(\mathrm{USD} \mathrm{ha}^{-1}\right) r=5.3 \%$} & \multicolumn{3}{|c|}{ REDD+ payment (USD $\left.\mathrm{tCO}_{2}\right) r=5.3 \%$} \\
\hline & & $\begin{array}{l}\text { Minimum } \\
\text { wage rate }\end{array}$ & $\begin{array}{l}\text { Village } \\
\text { wage rate }\end{array}$ & $\begin{array}{l}\text { Zero } \\
\text { wage rate }\end{array}$ & $\begin{array}{l}\text { Minimum } \\
\text { wage rate }\end{array}$ & $\begin{array}{l}\text { Village } \\
\text { wage rate }\end{array}$ & $\begin{array}{l}\text { Zero } \\
\text { wage rate }\end{array}$ \\
\hline \multirow{3}{*}{$\begin{array}{l}\text { Dense } \\
\text { miombo }\end{array}$} & Kunke & 4,916 & 5,006 & 5,631 & 25 & 25 & 28 \\
\hline & Maseyu & 1,824 & 1,363 & 2,860 & 9 & 7 & 14 \\
\hline & Mlimbilo & 2,452 & 2,633 & 3,177 & 12 & 13 & 16 \\
\hline \multirow{3}{*}{$\begin{array}{l}\text { Degraded } \\
\text { miombo }\end{array}$} & Kunke & 4,866 & 4,932 & 5,490 & 38 & 39 & 43 \\
\hline & Maseyu & 1,775 & 1,289 & 2,719 & 14 & 10 & 21 \\
\hline & Mlimbilo & 2,402 & 2,559 & 3,036 & 19 & 20 & 24 \\
\hline \multirow{4}{*}{$\begin{array}{c}\text { Montane } \\
\text { forest }\end{array}$} & Ng'ungulu & 1,823 & 1,580 & 3,991 & 1 & 1 & 2 \\
\hline & Nyandira & 4,791 & 4,660 & 6,277 & 3 & 3 & 4 \\
\hline & Tchenzema & 1,965 & 1,482 & 5,397 & 1 & 1 & 3 \\
\hline & Vinile & 2,287 & 2,067 & 5,156 & 1 & 1 & 3 \\
\hline
\end{tabular}

relatively dense miombo woodlands were significantly higher compared to after deforesting the degraded miombo woodlands (Fig. 4).

\subsection{Sensitivity analysis}

When village wage rate is considered, an increase in discount rate from $5.3 \%$ to $10 \%$ can reduce the median compensation values by about $50 \%$ in the lowland and by up to $30 \%$ in the highland zone (Table 10). Similarly, a $10 \%$ increase and reduction in carbon density can result in a $9 \%$ increase and an $11 \%$ reduction in the median compensation estimates, respectively. Moreover, the median compensations would increase by $100 \%$ for a $50 \%$ reduction in carbon density and decrease by $33 \%$ for a $50 \%$ increase in carbon density. The midpoint yield elasticity (0.274) of agricultural rent obtained from the production function showed that the results are not sensitive to changes in yield.

\section{Discussion: implications for REDD+ implementation design}

\subsection{Agricultural rent}

Variations in the median NPV were clearly related to crop types in both agroecological zones. We observed relatively higher median NPV estimates for villages with the highest percentage share of the most profitable crops. The reasons for choosing a certain crop type included agro-ecological considerations, distance to the nearest market, and farmland size. In Kunke, for example, sugarcane was the most profitable crop type cultivated on farmlands located close to the sugar factory; farmers able to grow sugarcane on 5 ha of land or more were able to sell their produce to the sugar factory. By contrast, rice, one of the most profitable crop types, is cultivated only in places with enough water, including Kunke and Mlimbilo but not Maseyu. In the highland zone, the continuous availability of water allows the local communities to cultivate vegetables (the most profitable crops in the highland villages) all year 

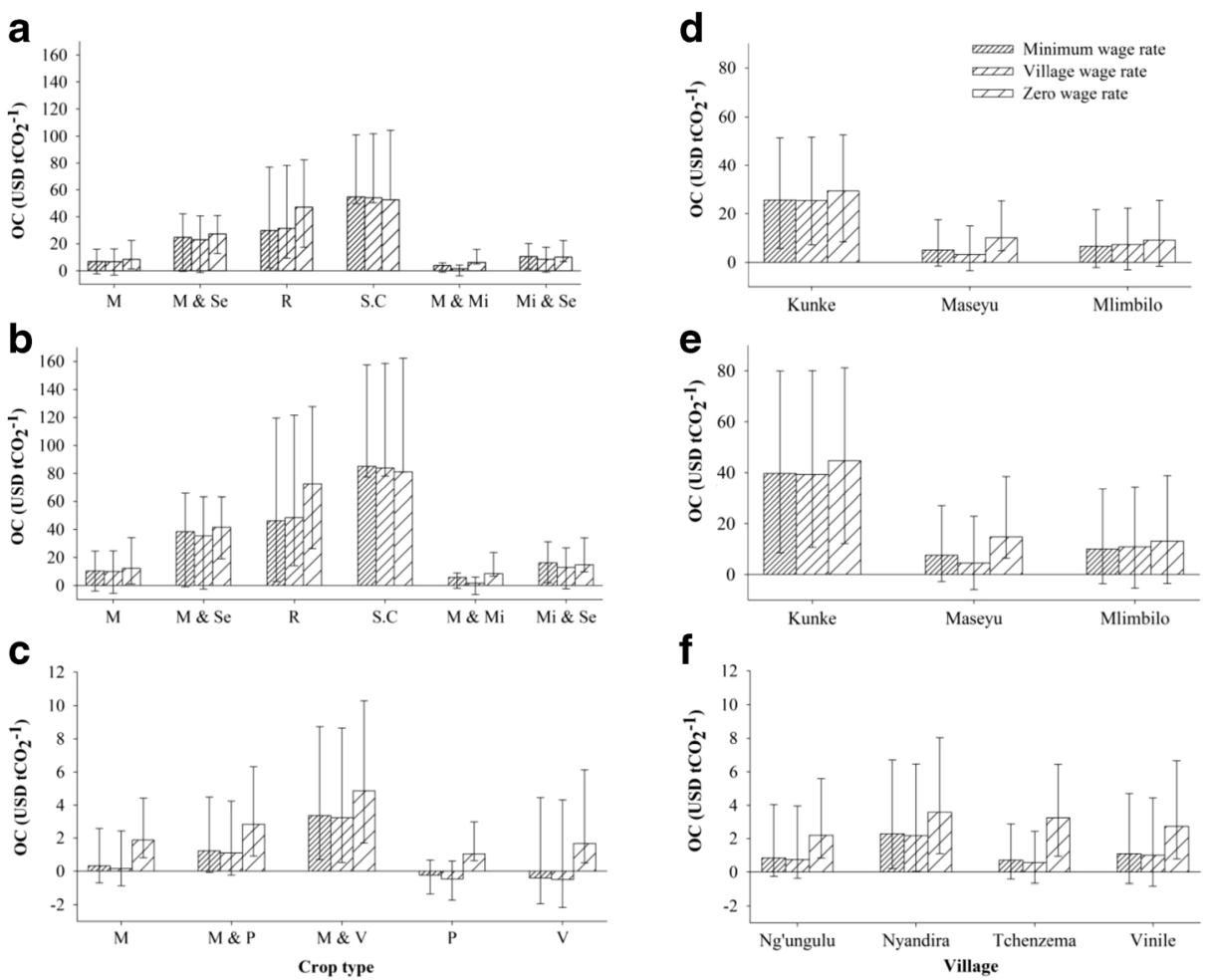

Fig. 4 The median compensation (USD tCO ${ }^{-1}$ ) by crop type $(\mathbf{a}, \mathbf{b}, \mathbf{c})$ and village $(\mathbf{d}, \mathbf{e}, \mathbf{f})$ in the lowland (dense miombo) (upper panel), lowland (degraded miombo) (middle panel), and highland (lower panel); the lower and upper error bars represent first and third quartiles, respectively. $M$ maize, $M i$ millet, $P$ pulses, $R$ rice, $S . C$ sugarcane, Se sesame, $V$ vegetables

round. However, in villages located farthest from the local market in Nyandira, such as Ng'ungulu, the cultivation of vegetables is limited.

Our analysis of agricultural rent showed a high variation in and a skewed distribution of NPV. The majority of farmers earned little income from the cultivation of crops, and only a few were able to make high profits. Hence, for a given REDD+ payment, normally a few families would still find it more profitable to continue to practice deforestation rather than accept the compensation and stop expanding their croplands. Few buyers would find it profitable to offer a sufficiently high price to convince the most efficient farmers to stop deforestation.

Labor input is an important component of crop production, and it can be broadly categorized into family labor and hired labor. Labor was abundant in the study villages, and the main source was family labor, particularly in the highland zone. Family labor accounted for more than $90 \%$ of the total labor used in crop production in the highland zone and $70 \%$ in the lowland zone. With the exception of Kunke, significant variation was found in all study villages in the median NPV of crop production between those estimated with regard to the positive $\mathrm{OC}$ of labor and those estimated using the zero OC of labor. The variation was higher in three villages in the highland zone because the main activities, such as land preparation, were undertaken using family labor. For some farm tasks that might require more labor, such as weeding, labor exchanges among relatives and neighbors were practiced. By contrast, in the lowland zone, particularly in Kunke and in some parts of Mlimbilo, some of the major tasks 
Table 10 Results of the sensitivity analysis of REDD+ payments $\left(\mathrm{USD} \mathrm{tCO}_{2}^{-1}\right)$

\begin{tabular}{|c|c|c|c|c|c|c|c|c|c|c|c|}
\hline \multirow{4}{*}{$\begin{array}{l}\text { Vegetation } \\
\text { type }\end{array}$} & \multirow[t]{4}{*}{ Village } & \multicolumn{10}{|c|}{$\mathrm{REDD}+$ payment $\left(\mathrm{USD} \mathrm{tCO}_{2}^{-1}\right)$} \\
\hline & & \multirow{2}{*}{\multicolumn{2}{|c|}{$\begin{array}{l}\text { Discount rate } \\
(r) \\
r=10 \%\end{array}$}} & \multicolumn{8}{|c|}{ Carbon density (C) } \\
\hline & & & & \multicolumn{2}{|l|}{$+10 \%$} & \multicolumn{2}{|l|}{$-10 \%$} & \multicolumn{2}{|l|}{$+50 \%$} & \multicolumn{2}{|l|}{$-50 \%$} \\
\hline & & $\begin{array}{l}\text { Village } \\
\text { wage } \\
\text { rate }\end{array}$ & $\begin{array}{l}\text { Zero } \\
\text { wage } \\
\text { rate }\end{array}$ & $\begin{array}{l}\text { Village } \\
\text { wage } \\
\text { rate }\end{array}$ & $\begin{array}{l}\text { Zero } \\
\text { wage } \\
\text { rate }\end{array}$ & $\begin{array}{l}\text { Village } \\
\text { wage } \\
\text { rate }\end{array}$ & $\begin{array}{l}\text { Zero } \\
\text { wage } \\
\text { rate }\end{array}$ & $\begin{array}{l}\text { Village } \\
\text { wage } \\
\text { rate }\end{array}$ & $\begin{array}{l}\text { Zero } \\
\text { wage } \\
\text { rate }\end{array}$ & $\begin{array}{l}\text { Village } \\
\text { wage } \\
\text { rate }\end{array}$ & $\begin{array}{l}\text { Zero } \\
\text { wage } \\
\text { rate }\end{array}$ \\
\hline \multirow{3}{*}{$\begin{array}{l}\text { Dense } \\
\text { miombo }\end{array}$} & Kunke & 14 & 17 & 23 & 26 & 28 & 31 & 17 & 19 & 50 & 56 \\
\hline & Maseyu & 4 & 9 & 6 & 13 & 8 & 16 & 5 & 10 & 14 & 29 \\
\hline & Mlimbilo & 8 & 10 & 12 & 14 & 15 & 18 & 9 & 11 & 26 & 32 \\
\hline \multirow{3}{*}{$\begin{array}{l}\text { Degraded } \\
\text { miombo }\end{array}$} & Kunke & 20 & 23 & 35 & 39 & 43 & 48 & 26 & 29 & 77 & 86 \\
\hline & Maseyu & 5 & 12 & 9 & 19 & 11 & 24 & 7 & 14 & 20 & 42 \\
\hline & Mlimbilo & 11 & 13 & 18 & 22 & 22 & 26 & 13 & 16 & 40 & 47 \\
\hline \multirow{4}{*}{$\begin{array}{c}\text { Montane } \\
\text { forest }\end{array}$} & Ng'ungulu & 1 & 2 & 1 & 2 & 1 & 3 & 1 & 2 & 2 & 5 \\
\hline & Nyandira & 2 & 3 & 2 & 3 & 3 & 4 & 2 & 2 & 5 & 7 \\
\hline & Tchenzema & 1 & 2 & 1 & 3 & 1 & 3 & 1 & 2 & 2 & 6 \\
\hline & Vinile & 1 & 2 & 1 & 3 & 1 & 3 & 1 & 2 & 2 & 6 \\
\hline
\end{tabular}

were carried out by hired labor due to suitability of the area for using machinery such as tractors. The sugar factory took responsibility for harvesting on the sugarcane plantation. Our results show the significance of crop production in terms of providing employment opportunities for the villagers. The difference between the NPV values estimated using a zero labor cost and those estimated using a positive labor cost can be seen as foregone benefits in terms of lost employment opportunities. In places such as the areas in which the study villages were located, where there are no readily available alternative sources of income, forgone employment opportunities need to be considered when a REDD+ policy is designed. The availability of family labor together with the profitability of crop production, particularly in the lowland zone, implies that the villagers have possibilities and incentives for increasing their farm size wherever land is suitable. Further intensification of their high-value crops implies greater increases in the costs of implementing the REDD+ policy measure.

\subsection{Forest rent}

The results showed that sustainable wood harvests from the montane forest and from both dense and degraded miombo woodlands resulted in a significantly higher NPV compared to the net returns from wood harvest during conversion to croplands. This was due to the relatively low discount rate used in the NPV estimation.

\subsection{The OC of stopping conversion of forestland to cropland}

The income that would be lost during conversion is significant. The OC originating from wood harvest during land clearing was significantly higher in the highland zone, but it was offset by the relatively higher return from sustainable harvest in the zone. In the case of miombo woodlands, no difference in OC estimates was observed between the woodlands in the forest 
reserve and those on public land. The return from charcoal production during forest conversion was higher from miombo woodlands in the forest reserve compared to miombo woodlands on public land, mainly due to the relatively higher biomass density in the former case. However, since the return from sustainable harvest was also higher from miombo woodlands in the forest reserve than on public land, the $\mathrm{OC}$ was offset. The results also highlighted the significance of sustainable harvests in offsetting some of the OCs, depending on the biomass density of the vegetation. In places, such as the areas occupied by the study villages, where more than $90 \%$ of the local people depend on biomass energy, such incentives might be more realistic and attractive to local communities than monetary incentives (Mohammed 2011). According to Kaczan et al. (2013), compared to cash payments, non-monetary payments in the form of fertilizers would motivate farmers' participation in reducing the degradation of forests of the Usambara Mountains in Tanzania. Consideration of such measures under the REDD+ scheme can be important in terms of minimizing OCs. However, depending on the forest products that are considered to be harvested sustainably, such incentives can also involve high management costs and therefore increase the implementation cost of the REDD+ policy. For example, in the studied villages, the firewood collected from the montane forest does not require much management input, but the harvesting of wood from miombo woodlands for charcoal production would require additional management costs if the harvesting were to be kept within sustainable limits.

\subsection{REDD+ payments to offset OCs}

The results of our analysis showed significant variation in the median compensation required to protect the different vegetation types in the two agro-ecological zones. Several researchers have noted variations in the OCs of emission reduction among tropical locations, depending on ecological and economic conditions (e.g., Grieg-Gran 2008; Strassburg et al. 2009). Further, Fisher et al. (2011) reported a variation (IQR=USD 3.20-5.50 $\mathrm{tCO}_{2}^{-1}$ ) in the OCs of avoiding agricultural expansion and charcoal production between 53 districts in eastern Tanzania. In our study, the main difference in the OCs was attributed to variations in biomass (carbon) density between the two vegetation types, and between the miombo woodland in forest reserve and on public land. When labor was valued as cheap, the NPV (USD ha ${ }^{-1}$ ) of agricultural production was not significantly different between the highland and lowland agro-ecological zones. However, due to pronounced differences in biomass density between the montane forest in the highland and the miombo woodland in the lowland zone, the $\mathrm{OC}$ per ton of $\mathrm{CO}_{2}$ was significantly different. These findings support those of (Yamamoto and Takeuchi 2012), who have pointed out the significance of variations in carbon density due to vegetation and soil conditions for significant differences in REDD+ compensation estimates. Our estimates of REDD+ payments required to protect the montane forest are similar to estimates reported for humid tropical forests with equivalent carbon densities (e.g., Bellassen and Gitz. 2008; Yamamoto and Takeuchi 2012). However, our estimates for the miombo woodlands are higher than estimates of REDD+ compensation payments reported for other miombo woodlands. For example, Bond et al. (2010) estimated that the regional OC of avoiding the conversion of miombo woodlands to agricultural lands would range from about USD $2.5 \mathrm{tCO}_{2}^{-1}$ for Namibia and Mozambique to USD $3.71 \mathrm{tCO}_{2}^{-1}$ for Zambia. The differences in compensation estimates are due to variations in assumptions regarding time horizon, discount rate, and carbon density. For example, Bond et al. (2010) used a discount rate of $10 \%$ p.a. and planning period of 30 years. The carbon density considered ranged from 45 to $60 \mathrm{tC} \mathrm{ha}{ }^{-1}$, which are between double and triple the carbon density used in our analysis. The net returns to cultivation reported are also significantly lower than the agricultural rents found in our study area. 
The differences in estimated carbon payments between the villages within each agro-ecological zone were due to variations in the NPV estimates of crop production, which were attributed to differences in crop type. The highest value was observed for Kunke, mainly due to the relatively high profits from sugarcane and rice cultivation. Variations in compensation values due to differences in farming system (subsistence and cash crop cultivation) have also been noted by Bellassen and Gitz (2008) and by Olsen and Bishop (2009). During our study, we observed that the prices of sugarcane and rice were lower than elsewhere in Tanzania. Based on the information gathered from the growers, we anticipate that the prices of the crops will increase in the near future and may thus increase the profitability of cultivating these crops, which would imply that the potential change in the prices of some crops should be taken into account when designing a REDD+ policy.

Our results suggest that implementing a REDD+ policy may be feasible in the highland agro-ecological zone, where considerable emission reduction could be achieved for a payment of less than the current carbon price (USD $5 \mathrm{tCO}_{2}{ }^{-1}$ ) in the European market (McGrath 2013). Regarding the miombo woodlands, we found that it would be comparatively cheaper to protect the denser miombo woodlands in the forest reserves than the more degraded miombo woodlands on public land. However, the implementation of the REDD+ policy in the lowland zone would generally require higher compensation payments. Further, the analysis was based on assumed carbon payments at stump, which means that the actual carbon payment might be higher than our estimates. Moreover, incorporating implementation costs which according to Fisher et al. (2011) are estimated to be USD $6.50 \mathrm{CO}_{2}^{-1}$ on average would further increase the cost of the policy measure.

Our results suggest that implementing the REDD+ scheme may be feasible if the biomass (carbon) density in the studied vegetation is high. However, the relatively dense miombo woodlands and intact montane forest are currently protected as forest reserves, and the present REDD+ schemes do not distinguish official protection status of areas. Nevertheless, implementing REDD + in the existing protected forests could be an effective and a feasible measure to cut $\mathrm{CO}_{2}$ emissions, mainly for three reasons. First, deforestation and degradation is significant in protected areas. For example, between 1975 and 2000, $3.4 \%$ of forest and $28.3 \%$ of miombo woodland were lost from the EAM (Green et al. 2013). Currently, respectively $74 \%$ and $32 \%$ of the remaining forest and woodland in the EAM are within protected areas (Green et al. 2013). Coastal forests in protected areas have been declining too, at a rate of $0.2 \%$ per year since the 1990s (Godoy et al. 2011). Similarly, miombo woodland in the KFR has declined by $6 \%$ between 1964 and 1996 (Luoga et al. 2005). The statistics imply that law enforcement efforts alone have not been sufficient to protect Tanzania's forests, and therefore economic measures are required to enforce effective protection.

The second reason why implementing REDD + in the existing protected forests could be an effective and a feasible measure to cut $\mathrm{CO}_{2}$ emissions is that the available carbon density in protected forests and woodlands is relatively high compared to forests and woodlands on public land, and the third reason is that the total cost of establishing new forest reserves would be higher than maintaining the existing ones. The median annual actual and necessary management costs in the EAM are estimated to be USD $2.3 \mathrm{ha}^{-1}$ (IQR=USD 1-6 ha ${ }^{-1}$ ) and USD $8.3 \mathrm{ha}^{-1}\left(\mathrm{IQR}=\mathrm{USD} 5-17 \mathrm{ha}^{-1}\right)$, respectively (Green et al. 2012), and are much lower than USD $0.1 \mathrm{tCO}_{2}^{-1}$. Thus, implementation of the REDD+ policy could be an opportunity to help strengthen established protected areas. Given the fact that about $50 \%$ of Tanzania's 
forests and woodlands are within forest reserves, it would be logical to invest in the existing reserves.

\subsection{Sensitivity analysis}

As with all land valuations, high discount rates imply lower land values, and in the case study also lower compensation levels. Given the level of poverty persisting in rural Tanzania, a discount rate of $10 \%$ per annum may not be entirely unrealistic in estimations of OCs. Most inhabitants in areas of miombo woodland have a very low income and they often prefer immediate consumption, which means they have to apply high discount rates (Bond et al. 2010). In the case of the lowland agroecological zone, the increase in discount rate meant that the compensation level in Maseyu was reasonable. Similarly, the implementation of the REDD+ policy could be feasible in Maseyu if the carbon density of the dense miombo is $50 \%$ higher than the density we gathered from secondary sources. On the other hand, a decrease of up to $50 \%$ in the carbon density of the montane forest would not lead to a level where it would become infeasible to invest in reduced emissions, particularly when a positive wage rate is considered. A positive wage rate may be a realistic assumption in areas where rural people can find alternative employment.

\section{Conclusions}

Knowledge of the monetary incentives required to avoid or reduce deforestation and forest degradation in various areas under different settings can help to identify economically feasible locations for the implementation of the REDD+ policy. Our study estimated the financial incentives required to stop the deforestation of both the montane forest in the highland agro-ecological zone and the miombo woodlands in the lowland agro-ecological zone of Morogoro Region, Tanzania. The median compensation required to protect the current carbon stock in the two vegetation types ranged from US\$ $1 \mathrm{tCO}_{2} \mathrm{e}^{-1}$ for the montane forest to US\$ $39 \mathrm{tCO}_{2} \mathrm{e}^{-1}$ for the degraded miombo woodlands. Our analysis revealed that the level of compensation required to avoid the forestland from being converted into cropland depended mainly on the biomass (carbon) density of the vegetation to be protected. Variations in assumptions regarding the OCs of labor and discount rate resulted in significant variations in the $\mathrm{OC}$ estimates and hence also the compensation levels between the two agro-ecological zones and between villages within the same agro-ecological zone. In such places as where our study villages were located, where there are few employment opportunities to compensate farmers for the reduction in work as a consequence of implementing REDD + , the level of compensation should be relatively higher. The choice of crop types attributed to both agro-ecological conditions and market access is an important factor in determining the feasibility of the implementation of the policy measure. From our study, we can conclude that given all possible factors that can potentially affect estimates of REDD+ payments, it would be more feasible to implement the policy in the highland zone than in the lowland zone. Depending on the biomass density of the vegetation to be protected, sustainable wood harvesting could be an important incentive under the REDD+ scheme. Moreover, considering factors such as available biomass density, implementation and management costs, and the degree of existing deforestation, the implementation of the 
REDD + policy in existing protected areas could be a feasible and effective way to reduce emissions of $\mathrm{CO}_{2}$.

Acknowledgments The fieldwork was financed by the Climate Change Impacts, Adaptation and Mitigation (CCIAM) program, and we are grateful to Professor L. O. Eik and Professor S. M. S. Maliondo for organizing the program. We would also like to thank Celina Nombo, Abuu Chanafi, and Daniel Jaleta for their contribution to the data collection.

Open Access This article is distributed under the terms of the Creative Commons Attribution License which permits any use, distribution, and reproduction in any medium, provided the original author(s) and the source are credited.

\section{References}

Angelsen A (2008) Moving ahead with REDD: issues, options and implications. Center for International Forestry Research (CIFOR), Bogor

Angelsen A, Shitindi EFK, Aarrestad J (1999) Why do farmers expand their land into forests? Theories and evidence from Tanzania. Environ Dev Econ 4(3):313-331

Angelsen A, Brockhaus M, Sunderlin WD, Verchot LV (2012) Analysing REDD+: challenges and choices. Center for International Forestry Research (CIFOR), Bogor

Barbier EB, Burgess JC (1997) The economics of tropical forest land use options. Land Econ 73(2):174-195

Bellassen V, Gitz V (2008) Reducing emissions from deforestation and degradation in Cameroon-assessing costs and benefits. Ecol Econ 68(1-2):336-344

Bond I, Grieg-Gran M, Wertz-Kanounnikoff S, Hazlewood P, Wunder S, Angelsen A (2009) Incentives to sustain forest ecosystem services: a review and lessons for REDD. Natural Resource Issues 16. International Institute for Environment and Development, London

Bond I, Chambwera M, Jones B, Chundama M, Nhantumbo I (2010) REDD+ in dryland forests: issues and prospects for pro-poor REDD in the miombo woodlands of southern Africa. Natural Resource Issues 21. International Institute for Environment and Development, London

Bosetti V, Rose SK (2011) Reducing carbon emissions from deforestation and forest degradation: issues for policy design and implementation. Environ Dev Econ 16(Special Issue 4):357-360

BOT (2011) Monthly economic review. Bank of Tanzania, Dar es Salaam

Burgess N, Doggart N, Lovett JC (2002) The Uluguru Mountains of eastern Tanzania: the effect of forest loss on biodiversity. Oryx 36(02):140-152

Burgess ND, Bahane B, Clairs T, Danielsen F, Dalsgaard S, Funder M, Hagelberg N, Harrison P, Haule C, Kabalimu K, Kilahama F, Kilawe E, Lewis SL, Lovett JC, Lyatuu G, Marshall AR, Meshack C, Miles L, Milledge SAH, Munishi PKT, Nashanda E, Shirima D, Swetnam RD, Willcock S, Williams A, Zahabu (2010) Getting ready for REDD+ in Tanzania: a case study of progress and challenges. Oryx 44(3):339-351

Butler RA, Koh LP, Ghazoul J (2009) REDD in the red: palm oil could undermine carbon payment schemes. Conserv Lett 2(2):67-73

Campbell BM (1996) The Miombo in transition: woodlands and welfare in Africa. CIFOR, Bogor

Chamshama SAO, Mugasha AG, Zahabu E (2004) Stand biomass and volume estimation for Miombo woodlands at Kitulangalo, Morogoro, Tanzania. South Forest J Forest Sci 200(1):59-70

Dudley R (2010) A little REDD model to quickly compare possible baseline and policy scenarios for reducing emissions from deforestation and forest degradation. Mitig Adapt Strateg Glob Chang 15(1):53-69

Ek T (1994) Biomass structure in miombo woodland and semi-evergreen forest. Development in twenty-two permanent plots in Morogoro, Tanzania. MSc thesis, Norwegian University of Life Sciences (UMB)

FAO (2005) Global forest resources assessment. Food and Agriculture Organization of the United Nations, Rome

FAO (2010) Global forest resources assessment. Food and Agriculture Organization of the United Nations, Rome

FBD (2009) Management plan for Uluguru Nature Reserve. Ministry of Natural Resources and Tourism: Forestry and Beekeeping Division, Morogoro

FBD (2010) Quantification and valuation of carbon stocks in the Uluguru and Chome Nature Reserves, Eastern Arc Mountains, Tanzania. Ministry of Natural Resources and Tourism: Forestry and Beekeeping Division, Morogoro

Fisher M, Shively GE, Buccola S (2005) Activity choice, labor allocation, and forest use in Malawi. Land Econ 81(4):503-517 
Fisher B, Lewis S, Burgess ND, Malimbwi RE, Munishi PK, Swetnam RD, Kerry Turner R, Willcock S, Balmford A (2011) Implementation and opportunity costs of reducing deforestation and forest degradation in Tanzania. Nat Clim Chang 1(3):161-164

Frontier-Tanzania (2005) Uluguru component biodiversity survey: Uluguru South Forest Reserve. In: Society for Environmental Exploration and the University of Dar es Salaam; CARE-Tanzania, Conservation and Management of the Eastern Arc Mountain Forests (CMEAMF): Uluguru Component, Forestry and Beekeeping Division of the Ministry of Natural Resources and Tourism

Godoy FL, Tabor K, Burgess ND, Mbilinyi BP, Kashaigili JJ, Steininger MK (2011) Deforestation and $\mathrm{CO}_{2}$ emissions in coastal Tanzania from 1990 to 2007. Environ Conserv FirstView:1-10

Green JM, Burgess ND, Green RE, Madoffe SS, Munishi PK, Nashanda E, Kerry Turner R, Balmford A (2012) Estimating management costs of protected areas: a novel approach from the Eastern Arc Mountains, Tanzania. Biol Conserv 150(1):5-14

Green JMH, Larrosa C, Burgess ND, Balmford A, Johnston A, Mbilinyi BP, Platts PJ, Coad L (2013) Deforestation in an African biodiversity hotspot: extent, variation and the effectiveness of protected areas. Biol Conserv 164:62-72

Grieg-Gran M (2008) The cost of avoiding deforestation. Update of the report prepared for the Stern Review of the economics of climate change. International Institute for Environment and Development, London

Grieg-Gran M, Chomitz K, Hyde B, Muñoz C, Richards M, Sedjo R, Stage J, Steele P, Tomich T, Vargas M-t (2006) The cost of avoiding deforestation. Report prepared for the Stern Review of the economics of climate change. International Institute for Environment and Development, London

Hofstad O (1997) Woodland deforestation by charcoal supply to Dar es Salaam. J Environ Econ Manag 33(1):17-32

Howarth RB, Norgaard RB (1992) Environmental valuation under sustainable development. Am Econ Rev 82(2):473-477

Kaczan D, Swallow BM, Adamowicz WL (2013) Designing a payments for ecosystem services (PES) program to reduce deforestation in Tanzania: an assessment of payment approaches. Ecol Econ 95:20-30

Kaimowitz D, Angelsen A (1998) Economic models of tropical deforestation: a review. CIFOR, Bogor

Kapilima WHE (1994) Establishing a research scheme for small vegetable growers: the case of upper Mgeta Horticultural Development Project Morogoro Tanzania. Acta Horticult 369:399-408

Karky BS, Skutsch M (2010) The cost of carbon abatement through community forest management in Nepal Himalaya. Ecol Econ 69(3):666-672

Kindermann G, Obersteiner M, Sohngen B, Sathaye J, Andrasko K, Rametsteiner E, Schlamadinger B, Wunder S, Beach R (2008) Global cost estimates of reducing carbon emissions through avoided deforestation. Proc Natl Acad Sci U S A 105(30):10302-10307

Kissinger G, Herold M, Sy VD (2012) Drivers of deforestation and forest degradation: a synthesis report for REDD+ policymakers. Lexeme Consulting, Vancouver

Le KT (2009) Shadow wages and shadow income in farmers' labor supply functions. Am J Agric Econ 91(3): 685-696

Lovett JC, Pócs T (1993) Assessment of the condition of the Catchment Forest Reserves, a botanical appraisal: Irnga region. Catchment For Rep 93:3

Lundgren L (1978) Studies of soil and vegetation development on fresh landslide scars in the Mgeta Valley, Western Uluguru Mountains, Tanzania. Geogr Ann A 60(3-4):91-127

Luoga EJ, Witkowski ETF, Balkwill K (2000) Economics of charcoal production in miombo woodlands of eastern Tanzania: some hidden costs associated with commercialization of the resources. Ecol Econ 35(2):243-257

Luoga EJ, Witkowski ETF, Balkwill K (2002) Harvested and standing wood stocks in protected and communal miombo woodlands of eastern Tanzania. Forest Ecol Manag 164(1-3):15-30

Luoga EJ, Witkowski ETF, Balkwill K (2005) Land cover and use changes in relation to the institutional framework and tenure of land and resources in eastern Tanzania miombo woodlands. Environ Dev Sustain 7(1):71-93

Madulu NF (2005) Environment, poverty and health linkages in the Wami River basin: a search for sustainable water resource management. Phys Chem Earth Pt A/B/C 30(11-16):950-960

Makundi WR, Okiting'ati A (1995) Carbon flows and economic evaluation of mitigation options in Tanzania's forest sector. Biomass Bioenerg 8(5):381-393

Malimbiwi RE, Solberg B, Luoga E (1994) Estimation of biomass and volume in miombo woodland at Kitulangalo Forest Reserve, Tanzania. Trop Forest Sci 7(2):230-242

Malimbwi RE, Zahabu E, Monela GC (2005) Charcoal potential of miombo woodlands at Kitulangalo, Tanzania. Trop Forest Sci 17(2):197-210

Mbwambo L, Eid T, Malimbwi RE, Zahabu E, Kajembe GC, Luoga E (2012) Impact of decentralised forest management on forest resource conditions in Tanzania. Forests Trees Livelihoods 21(2):97-113

McGrath M (2013) EU parliament rejects plan to boost carbon trading BBC. http://www.bbc.com/news/scienceenvironment-22167675. Cited 16 April 2013 
Mitinje E, Kessy JF, Mombo F (2007) Socio-economic factors influencing deforestation on the Uluguru Mountains, Morogoro, Tanzania. Discov Innov 19(Special Edition (1-2)):139-148

Mohammed EY (2011) Pro-poor benefit distribution in REDD+: who gets what and why does it matter? REDD Working Paper. International Institute for Environment and Development, London

Monela GC, O'Kting'ati A, Kiwele PM (1993) Socio-economic aspects of charcoal consumption and environmental consequences along the Dar es Salaam-Morogoro highway, Tanzania. Forest Ecol Manag 58(3-4):249-258

Munishi PKT, Shear TH (2004) Carbon storage in afromontane rain forests of the Eastern Arc mountains of Tanzania: their net contribution to atmospheric carbon. Trop Forest Sci 16(1):78-93

Munishi PKT, Mringi S, Shirima DD, Linda SK (2010) The role of the miombo woodlands of the Southern Highlands of Tanzania as carbon sinks. Ecol Nat Environ 2(12):261-269

Muthike G, Kanali C, Shitanda D (2013) Comparative analysis of on-farm timber conversion systems in Kenya. J Hortic Forest 5(6):74-80

Nduwamungu J, Bloesch U, Munishi PKT, Hagedorn F, Lulu K (2008) Recent land cover and use changes in miombo woodlands of eastern Tanzania. Tanzania J Forest Nat Conserv 78(1):50-59

Olsen N, Bishop J (2009) The financial costs of REDD: evidence from Brazil and Indonesia. IUCN, Gland, Switzerland

Osborne T, Kiker C (2005) Carbon offsets as an economic alternative to large-scale logging: a case study in Guyana. Ecol Econ 52(4):481-496

Pelletier J, Kirby KR, Potvin C (2012) Significance of carbon stock uncertainties on emission reductions from deforestation and forest degradation in developing countries. Forest Policy Econ 24:3-11

Potvin C, Guay B, Pedroni L (2008) Is reducing emissions from deforestation financially feasible? A Panamanian case study. Clim Policy 8(1):23-40

Poynton JC, Loader SP, Sherratt E, Clarke BT (2007) Amphibian diversity in East African biodiversity hotspots: altitudinal and latitudinal patterns. In: Hawksworth D, Bull A (eds) Vertebrate conservation and biodiversity, vol 5. Springer, Dordrecht, pp 277-292

R Core Team (2013) R: a language and environment for statistical computing. R Foundation for Statistical Computing

Ryan CM, Williams M, Grace J (2011) Above- and belowground carbon stocks in a Miombo Woodland landscape of Mozambique. Biotropica 43(4):423-432

Shirima DD, Munishi PKT, Lewis SL, Burgess ND, Marshall AR, Balmford A, Swetnam RD, Zahabu EM (2011) Carbon storage, structure and composition of miombo woodlands in Tanzania's Eastern Arc Mountains. Afr J Ecol 49(3):332-342

Springate-Baginski O, Wollenberg E (2010) REDD, forest governance and rural livelihoods: the emerging agenda. Center for International Forestry Research (CIFOR), Bogor

Stern N (2007) The economics of climate change: the Stern review. Cambridge University Press, Cambridge

Strassburg B, Turner RK, Fisher B, Schaeffer R, Lovett A (2009) Reducing emissions from deforestation-the "combined incentives" mechanism and empirical simulations. Glob Environ Change 19(2):265-278

Systat Software Inc (2008) SigmaPlot: statistical data analysis and scientific graphing. Systat Software, San Jose van der Werf GR, Morton DC, DeFries RS, Olivier JGJ, Kasibhatla PS, Jackson RB, Collatz GJ, Randerson JT (2009) $\mathrm{CO}_{2}$ emissions from forest loss. Nat Geosci 2(11):737-738

Walker SM, Desanker PV (2004) The impact of land use on soil carbon in miombo woodlands of Malawi. Forest Ecol Manag 203(1-3):345-360

Wertz-Kanounnikoff S (2008) Estimating the costs of reducing forest emissions. Center for International Forestry Research (CIFOR), Bogor

Wertz-Kanounnikoff S, Kongphan-apirak M (2009) Emerging REDD+: a preliminary survey of demonstration and readiness activities. Center for International Forestry Research (CIFOR), Bogor

Willcock S, Phillips OL, Platts PJ, Balmford A, Burgess ND, Lovett JC, Ahrends A, Bayliss J, Doggart N, Doody K, Fanning E, Green J, Hall J, Howell KL, Marchant R, Marshall AR, Mbilinyi B, Munishi PKT, Owen N, Swetnam RD, Topp-Jorgensen EJ, Lewis SL (2012) Towards regional, error-bounded landscape carbon storage estimates for data-deficient areas of the world. PLoS ONE 7(9):e44795

Wollenberg E, Springate-Baginski O (2009) Incentives +: how can REDD improve well-being in forest communities? Center for International Forestry Research (CIFOR), Bogor

World Bank (2004) Sustaining forests: a development strategy. World Bank, Washington, DC

Wunder S, Wertz-Kanounnikoff S (2009) Payments for ecosystem services: a new way of conserving biodiversity in forests. J Sustain Forest 28(3-5):576-596

Yamamoto Y, Takeuchi K (2012) Estimating the break-even price for forest protection in Central Kalimantan. Environ Econ Policy Stud 14(3):289-301

Zahabu E (2008) Sinks and sources: a strategy to involve forest communities in Tanzania in global climate policy. $\mathrm{PhD}$ thesis, University of Twente

Zahabu E, Skutsch MM, Sosovele H, Malimbwi RE (2007) Reduced emissions from deforestation and degradation. Afr J Ecol 45(4):451-453 